\title{
PENERAPAN MODEL PEMBELAJARAN PROBLEM BASED LEARNING DALAM MENINGKATKAN HASIL BELAJAR SISWA PADA KONSEP SISTEM EKSKRESI MANUSIA DI KELAS XI SMA NEGERI 1 JANGKA BUYA
}

\author{
Zuraida $^{(1)}$, Zufahmi $^{(2)}$, Yuliana $^{(3)}$ \\ ${ }^{1,2,3}$ Program Studi Pendidikan Biologi Universitas Jabal Ghafur \\ e-mail:raidazuraida4@gmail.com
}

\begin{abstract}
ABSTRAK
Peneltian ini bertujuan untuk mengetahui penerapan model pembelajaran problem based learning dalam meningkatkan hasil belajar siswa pada konsep Sistem Ekskresi Manusia di Kelas XI SMA Negeri 1 Jangka Buya. Penelitian ini termasuk penelitian eksprimen. Populasi Penelitian adalah seluruh siswa kelas XI SMA Negeri 1 Jangka Buya dan Sampel diambil 2 kelas secara random yaitu $\mathrm{XI}_{1}$ sebagai kelas eksprimen dengan jumlah 24 siswa dan kelas $\mathrm{XI}_{3}$ sebagai kelas kontrol dengan jumlah siswa 24. Pengumpulan data dengan cara dokumentasi dan tes. Teknik analisis data dengan Analisispeningkatanhasilbelajar Gain yang dinormalisasi ( $\mathrm{N}$-gain) dan pengujian hipotesis uji independent sample t-test(Uji-t). Peningkatan hasil belajar menunjukkan Skor N-Gain berkategori sedang sebesar 0,60 pada kelas eksperimen dan kelas kontrol Skor N-Gain berkategori rendah dengan skor rerata 0,32. Hipotesis penelitian menggunakan uji-t diperoleh nilai $\mathrm{t}=5,91$ jadi $\mathrm{t}_{\text {hitung }}>\mathrm{t}_{\text {tabel }}$ yaitu 5,91 $>1,68$ dengan demikian Ha diterima dengan taraf signifikan $\alpha$ 0,05 maka dapat disimpulkan bahwa hipotesis dapat diterima kebenarannya. Berdasarkan hasil penelitian dapat disimpulkan bahwa penerapan model pembelajaranproblem based learning dapat meningkatkan hasil belajar siswa pada konsep sistem ekskresi pada manusia di SMA Negeri 1 Jangka Buya.
\end{abstract}

Kata Kunci: Penerapan, Problem Based Learning, Sistem Ekskresi Manusia, Hasil Belajar. 
Jurnal Sosial Humaniora Sigli (JSH)

p ISSN : 2615-3688

$e$ ISSN : 2716-0270

http://journal.unigha.ac.id/index.php/JSH

\section{PENDAHULUAN}

Pendidikan merupakan suatu kebutuhan yang harus dipenuhi dalam proses kehidupan. Majunya suatu bangsa dipengaruhi oleh mutu pendidikan dari bangsa itu sendiri karena pendidikan yang tinggi dapat mencetak Sumber Daya Manusia (SDM) yang berkualitas. Sumber daya manusia yang berkualitas adalah guru yang mampu membuat siswa mampu dan mencapai hasil belajar yang sesuai dengan yang diharapkan.

Salah satu pembelajaran yang diajarkan di sekolah adalah pembelajaran Biologi. Pusat pembelajaran dalam pelajaran Biologi ada pada siswa yang memberikan kesempatan kepada siswa untuk berpartisipasi aktif dalam pembelajaran sehingga mampu meningkatkan aktivitas belajar siswa dan kompetensi siswa (Noviar, 2015:42). Pembelajaran Biologi yang berpusat pada siswa dimaksudkan untuk melibatkan siswa dalam mengkonstruksi sendiri pengetahuannya sehingga siswa lebih dominan dalam pembelajaran. Hal tersebut dapat mengembangkan pengetahuan, keterampilan dan sikap percaya diri siswa. Selain itu, proses pembelajaran Biologi harus berdasarkan data dan fakta ilmiah agar diperoleh suatu pembelajaran yang bermakna (A'la, 2010 :176).

Tujuan pembelajaran Biologi yang ingin dicapai dari proses pendidikan adalah hasil belajar Biologi siswa yang meliputi ranah kognitif, afektif, dan psikomotor. Ketiga ranah tersebut merupakan satu kesatuan yang tidak dapat dipisahkan. Sementara itu, kegiatan pembelajaran Biologi selama ini kurang memberi kesempatan kepada siswa untuk berperan aktif dalam pembelajaran. Peranan guru masih sangat dominan dan kurang optimal dalam menggunakan pendekatan pembelajaran, sehingga membuat siswa kurang aktif dalam pembelajaran dan kualitas belajar siswa menjadi rendah. Kurang aktifnya siswa dalam pembelajaran Biologi tersebut akan menyebabkan konsep-konsep Biologi tidak bermakna dan selanjutnya tidak dapat dipahami dengan baik (Nurhidayat, 2011:3).

Permasalahan tersebut selaras dengan hasil observasi yang dilakukan di SMA Negeri 1 Jangka Buya bahwa pembelajaran Biologi yang dilakukan guru di kelas masih didominasi dengan metodediskusi biasa disertai dengan ceramah, belum menggunakan variasi model pembelajaran lainnya serta kurang memberikan gambaran yang nyata kepada siswa terkait materi yang sedang diajarkan. Hal tersebut mengakibatkan siswa tidak memperhatikan guru dan sibuk dengan temannya sendiri sehingga tujuan pembelajaran yang diharapkan tidak tercapai sesuai harapan.

Penerapan model pembelajaran bervariasi sangat dibutuhkan dalam meningkatkan hasil belajar siswa. Penerapan model-model pembelajaran yang bervariasi dapat membantu guru dalam proses belajar mengajar. Target pembelajaran yang diterapkan akan tercapai jika guru dalam hal ini memilih model pembelajaran yang tepat yang berisikan bahan yang diajarkan, kompetensi siswa serta sarana dan prasarana yang tersedia yang perlu dilakukan oleh guru sebagai bahan/tujuan dan ruang lingkupnya (Sakdiyah, 2010).

Salah satu model pembelajaran yang dapat digunakan adalah model problem based learning. Model pembelajaran problem based learning merupakan suatu pendekatan pembelajaran yang menggunakan masalah dunia nyata sebagai suatu konteks bagi siswa untuk belajar tentang cara berpikir kritis dan keterampilan pemecahan 
Jurnal Sosial Humaniora Sigli (JSH)

p ISSN : 2615-3688

$e$ ISSN : 2716-0270

http://journal.unigha.ac.id/index.php/JSH

masalah, serta untuk memperoleh pengetahuan dan konsep yang esensial dari materi pelajaran (Kamdi, 2007:77). Model problem based learning diharapkan dapat meningkatkan hasil belajar siswa terhadap konsep Biologi, karena siswa mengkonstruksi sendiri pengetahuan yang siswa dapatkan.

Penelitian ini didukung oleh hasil penelitian yang dilakukan oleh Magdalena (2016) mengatakan bahwa penerapan model pembelajaran problem based learning (PBL) dalam pembelajaran Biologi berpengaruh terhadap hasil belajar siswa SMA Negeri 5 kota Samarinda kelas XI tahun ajaran 2015. Selanjutnya Noviar (2015) mengatakan bahwa model problem based learning berbasis scientific approach secara signifikan dapat meningkatkan hasil belajar Biologi. Selanjutnya Febriani (2017) mengatakan bahwa model Problem Based Learning (PBL) berpengaruh signifikan terhadap kemampuan pemecahan masalah peserta didik pada mata biologi materi pencemaran lingkungan.

Berdasarkan pembahasan di atas, peneliti tertarik ingin melakukan penelitian dengan menggunakan penerapan model pembelajaran problem based learning pada konsep Sistem Ekskresi Manusia dengan judul "Penerapan Model Pembelajaran Problem Based Learning dalam Meningkatkan Hasil Belajar Siswa pada Konsep Sistem Ekskresi Manusia diKelas XI SMA Negeri 1 Jangka Buya".Berdasarkan rumusan masalahApakah dengan penerapan model pembelajaran problem based learning dapat meningkatkan hasil belajar siswa pada konsep Sistem Ekskresi Manusia di kelas XI SMA Negeri 1 Jangka Buya". Tujuan penelitian untuk mengetahui penerapan model pembelajaran problem based learningdalam meningkatkan hasil belajar siswa pada konsep Sistem Ekskresi Manusia di kelas XI SMA Negeri 1 Jangka Buya.Hipotesis dalam penelitian ini adalah: Penerapan model pembelajaran problem based learning dapat meningkatkan hasil belajar siswa pada konsep sistem ekskresi kelas XI SMA Negeri 1 Jangka Buya.

\section{METODE PENELITIAN}

\subsection{Pendekatan penelitian dan Jenis Penelitian}

Penelitian ini menggunakan pendekatan kuantitatif Sedangkan jenis penelitian ini adalah eksperimen.

\subsection{Desain Penelitian}

Desain penelitian ini berawal dari masalah yang bersifat kuantitatif dan membatasi permasalahan yang ada pada rumusan masalah. Rumusan masalah dinyatakan dalam kalimat pertanyaan, selanjutnya peneliti menggunakan teori untuk menjawabnya. Untuk melihat hasil belajar siswa digunakan rancangan penelitian praeksperimen (non desain) yaitu one-group pretest-posttest designsebagai berikut:

Tabel 3.1 Rancangan Penelitian

\begin{tabular}{|l|c|c|c|}
\hline Kelompok & $\begin{array}{c}\text { Pre- } \\
\text { test }\end{array}$ & Perlakuan & $\begin{array}{c}\text { Post- } \\
\text { test }\end{array}$ \\
\hline Kelas & $\mathrm{O}_{1}$ & $\mathrm{X}_{1}$ & $\mathrm{O}_{2}$ \\
Eksperimen & $\mathrm{O}_{1}$ & $\mathrm{X}_{2}$ & $\mathrm{O}_{2}$ \\
Kelas & & & \\
Kontrol & & & \\
\hline
\end{tabular}


Jurnal Sosial Humaniora Sigli (JSH)

p ISSN : 2615-3688

$e$ ISSN : 2716-0270

http://journal.unigha.ac.id/index.php/JSH

(Sumber: Arikunto, 2010:125)

Keterangan $\quad: \quad \mathrm{X}_{1}$ : Perlakuan

dengan pembelajaran problem based

learning

$$
\begin{gathered}
\mathrm{X}_{2}: \text { Perlakuan dengan } \\
\text { pembelajaran ceramah } \\
\mathrm{O}_{1}: \text { Tes Awal }(\text { Pre-test }) \\
\left.\mathrm{O}_{2}: \text { Tes Akhir (Post-test }\right)
\end{gathered}
$$

\subsection{Populasi dan Sampel Penelitian}

Populasi adalah wilayah
generalisasi yang terdiri atas obyek/subyek yang mempunyai kualitas dan karakteristik tertentu yang ditetapkan oleh peneliti untuk dipelajari dan kemudian ditarik kesimpulannya. Sampel adalah bagian dari jumlah dan karakteristik yang dimiliki oleh populasi tersebut (Sugiyono, 2009:117-118).

Populasi dalam penelitian ini adalah seluruh siswa kelas XI SMA Negeri 1 Jangka Buya Kabupaten Pidie Jaya. Sampel penelitian diambil dua kelas secara acak atau random, yang menjadi sampel dalam penelitian ini adalah siswa kelas $\mathrm{XI}_{1}$ berjumlah 24 siswa sebagai kelas eksperimen yang diajarkan dengan menggunakan model problem based learning dan kelas $\mathrm{XI}_{3}$ berjumlah 24 siswa sebagai kelas kontrol yang diajarkan tanpa menggunakan model problem based learning (model konvensional).

\subsection{Teknik Pengumpulan Data}

Teknik pengumpulan penelitian ini terdiri dari: Teknik dokumentasi dan Pemberian Tes.

\subsection{Teknik Analisis Data}

Setelah secara keseluruhan data terkumpul, tahap berikutnya adalah tahap pengolahan data. Salah satunya dengan cara menghitung peningkatan pemahaman konsep siswa dengan rumus gain ternormalisasi (N-gain) (Diadaptasi dari Hake, 1999 dalam Zuraida, 2019).

$$
\begin{aligned}
& \mathrm{N} \text { - Gain }=\frac{S_{\text {Post }}-S_{\text {Pre }}}{S_{\text {Max }}-S_{\text {Pre }}} \\
& \text { Keterangan: } \quad \text { N-Gain }=\text { Nilai } \\
& \text { Gain } \\
& \begin{array}{ll}
\mathrm{S}_{\text {post }} & =\text { Nilai Posttest } \\
\mathrm{S}_{\text {pre }} & =\text { Nilai Pree-test } \\
\mathrm{S}_{\max } & =\text { Nilai Maksimum }
\end{array}
\end{aligned}
$$

Data dari hasil hitung N-Gain tersebut kemudian dikonversi kriteria adalah sebagi berikut:

Tabel 3.2 Kriteria Normalized-Gain

\begin{tabular}{|c|c|}
\hline Skor N-Gain & Kriteria \\
\hline $0,70<$ N-Gain & Tinggi \\
\hline $0,30 \leq$ Gain $\leq$ & Sedang \\
0,70 & \\
\hline N-Gain $<0,30$ & Rendah \\
\hline
\end{tabular}

Tahap selanjutnya adalah pengolahan data dengan menggunakan statistik yang sesuai sehingga akan memberikan informasi yang selaras dengan hal yang diteliti yaitu uji - t (Sudjana, 2005:239):

$$
\mathrm{t}=\frac{\bar{x}_{1}-\bar{x}_{2}}{\sqrt{\frac{1}{n_{1}}+\frac{1}{n_{2}}}}
$$

Keterangan: $\mathrm{t} \quad=\mathrm{Uji}-\mathrm{t}$ 
Jurnal Sosial Humaniora Sigli (JSH)

p ISSN : 2615-3688

$e$ ISSN : 2716-0270

http://journal.unigha.ac.id/index.php/JSH

$$
\bar{x}_{1}=\text { nilai rata-rata }
$$

kelompok eksperimen

$$
\bar{x}_{2}=\text { nilai rata-rata }
$$

kelompok kontrol

$$
\mathrm{s} \quad=\text { Standar deviasi }
$$

$n_{l}=$ jumlah siswa kelas

eksperimen

$$
n_{2}=\text { jumlah siswa kelas }
$$

kontrol

\section{Hasil dan Pembahasan}

\subsection{Hasil Penelitian}

Penelitian ini dilaksanakan di kelas XISMA Negeri 1 Jangka Buya. Sampel dalam penelitian ini adalah siswa kelas $\mathrm{XI}_{1}$ berjumlah 24 siswa sebagai kelas eksperimen yang diajarkan dengan menggunakan model problem based learning dan kelas $\mathrm{XI}_{2}$ berjumlah 24 siswa sebagai kelas kontrol yang diajarkan tanpa menggunakan model problem based learning (model konvensional). Rancangan yang diambil dalam penelitian ini adalah praeksperimen (non desain) yaitu one-group pretestposttest design dengan membandingkan hasil siswa antara sebelum dan sesudah mendapat perlakuan. Pre-test diberikan untuk mengetahui kemampuan awal siswa terhadap konsep sistem ekskresi manusia dan post-test diberikan setelah proses pembelajaran di kedua kelas. Kelas eksperimen Hal ini dapat dilihat dari nilai rata-rata skor pre-test sebesar 1,86 dengan predikat $\mathrm{C}$ dan siswa yang mencapai ketuntasan belajar sebesar $4,17 \%$ siswa. Sedangkan hasil belajar siswa pada post-test terjadi peningkatan hasil belajar yang signifikan. Hal ini dapat dilihat dari nilai rata-rata skor posttest sebesar 3,16 dengan predikat $\mathrm{B}+$ dan siswa yang mencapai ketuntasan belajar pada post-test sebanyak $87,5 \%$ siswa. Hasil belajar siswa pada posttest kelas eksperimen ada peningkatan secara signifikan dibandingkan dengan hasil beajar pada pre-test. Hal ini dapat dilihat dari hasil analisis $\mathrm{N}$ gain sebesar 0,60 dan berada pada katagori sedang. Hasil menunjukan bahwa hasil belajar pre-test kelas kontrol diperoleh rata-rata skor 1,77 dengan predikat $\mathrm{C}$ - dan siswa tidak ada yang mencapai ketuntasan belajar di pre-test. Sedangkan rata-rata skor post-test 2,51 dengan katagori $\mathrm{C}+$ dan siswa yang mencapai ketuntasan belajar di post-test sebanyak 25\% siswa. Hasil belajar siswa (post-test) di kelas kontrol tidak adasignifikan dengan hasil pre-test. Hal dapat dilihat dari hasil analisis dengan menggunakan $\mathrm{N}$-gain sebesar 0,32 dan berada pada katagori rendah.

\subsection{Pembahasan}

Hasil analisis data dilakukan dengan menggunakan uji-t diperolah $\mathrm{t}_{\text {hitung }}(0,59)<\mathrm{t}_{\text {tabel }}(1,68)$ dengan derajat kebebasan (dk) 46. Hal ini menunjukan bahwa hasil belajar siswa atau kemampuan awal siswa sebelum diberikan perlakuan di kedua kelas baik kelas eksperimen maupun kelas kontrol pada konsep sistem eksresi pada manusia di SMA Negeri 1 Jangka Buya dapat dikatakan sama. Hasil belajar post-test kelas 
eksperimen lebih tinggi dibandingkan dengan kelas kontrol yaitu $\mathrm{t}_{\text {hitung }}(5,91)$ $>t_{\text {tabel }}(1,68)$. Hal ini membuktikan bahwa penerapan model pembelajaran problem based learning dapat meningkatkan hasil belajar siswa pada konsel sistem eksresi pada manusia di SMA Negeri 1 Jangka Buya.

$$
\text { Hasil belajar kelas }
$$

eksperiman menunjukkan bahwa terjadi peningkatan belajar siswa yang signifikan. Hal ini dapat dilihat dari peningkatan hasil belajar siswa di pretest sebesar1,86 dengan predikat $\mathrm{C}$ dan hasil belajar post-test sebesar 3,16 dengan predikat $\mathrm{B}+$. Peningkatan hasil belajar siswa di kelas eksperimen ada peningkatan secara signifikan dibandingkan dengan pretest yaitu sebesar 0,60 dan berada pada katagori sedang.

Hasil belajar kelas kontrol menunjukkan bahwa tidak ada signifikan dari pada hasil belajar siswa kelas eksperimen. Hal ini dapat dilihat dari peningkatan hasil belajar siswa di pre-test sebesar1,77 dengan predikat C- dan hasil belajar post-test sebesar 2,51 dengan katagori B-. Hasil belajar siswa (post-test) di kelas kontrol tidak ada signifikan dengan hasil pre-test yaitu sebesar 0,32 dan berada pada katagori rendah.

Hasil penelitian menunjukan bahwa hasil belajar siswa dengan menerapkan model pembelajaran problem based learning lebih baik dari hasil belajar siswa dengan menerapkan metode ceramah dan tanya jawab. Model problem based learning memberikan kesempatan siswa untuk mengembangkankemampuannya yang berkaitan denganketerampilan berkomunikasi, representasi, pemodelan, danpenalaran. Keterampilan tersebut diperoleh melaluikegiatan mengamati, menanya, mencoba, menalar,menyaji, dan mencipta yang kesemuanya merupakanproses-proses yang terdapat pada Scientific Approach(Machin, 2014:32).

Pelaksanaan pembelajaran pada kelas eksperimen dengan model pembelajaranproblem based learning berjalan melaluiskenario pembelajaran dimana kegiatan awal gurumemberikan apersepsi dan motivasi, dilanjutkandengan menyampaikan dan menayangkan topikpembelajaran serta menyampaikan dan menayangkantujuan atau kompetensi capaian setelah pembelajaran. Kegiatan inti pembelajaran gurumemberikan pembelajaran singkat selama 10 menit yang terkait dengan hal-hal yang perlu diperhatikandalam pemecahan masalah sistem ekskresi pada manusia yakniberupa tahapan pemecahan masalahan yang mengacupada model pembelajaran problem based learning, yakni merumuskan permasalahan, merumukan hipotesis,menyusun prosedur kerja, merumuskan hasilpemecahan masalahan dan pembuktian hipotesis, merumuskan kesimpulan, selanjutnya memberikan kesempatan kepada kelompok untuk Dikerjakan mempresentasikan hasil pembuatanlaporan pemecahan masalah yang olehkelompok dalam diskusi klasikal, dilanjutkandengan diskusi yang berisi pertanyaan sertatanggapan dari siswa yang ada pada kelompok yangtidak mendapat giliran presentasi.

Pada kegiatan intipembelajaran guru sebagai fasilitator, motifator, baikpada kegiatan diskusi maupun pada kegiatanmemberian kesempatan bertanya pada siswa di sesiakhir 
kegiatan inti yang berjalan selama 70 menit.Kegiatan penutup pembelajaran diisi dengan siswa membuat kesimpulan danguru memberikan rewordserta mengingatkan tugasindividual kepada siswa berupa pembuatan laporanpemecahan masalah secara mandiri dimana masalahsistem ekskresi pada manusia telah diperoleh siswa saatmelaksanakan kegiatan observasi secaraberkelompok, untuk dikerjakan di luar pembelajaran.Diakhir pembelajaran guru memberikan test. Jadi hasil belajar dalam penelitian ini diukur melalui hasiltest dan penilaian kinerja berupa tugas individualhasil pembuatan laporan pemecahan masalah terkaitsistem ekskresi secara mandiri oleh siswa. Pelaksanaan pembelajaran pada kelas kontrolberjalan melalui skenario pembelajaran pembelajaranlangsung (diarec learning) dengan kegiatan awal diisi oleh guru dengan melaksanakan apersepsimotivasi dan menayangkan serta menyampaikantopik dan tujuan atau kompetensi capaian setelahproses pembelajaran. Kegiatan inti terlaksana melaluikegiatan penjelasan guru terkait hal-hal yang harusdiperhatikan yakni tahapan pemecahan masalah,yakni penjelasan-penjelasan terkait denganobservasi, perumusan masalah, perumusan hipotesis,penyusunan prosedur kerja, hasil pemecahan masalahdan pembuktian hipotesis, serta penyusunankesimpulan. Setiap akhir penjelasan satu indikatorhal yang perlu diperhatikan dalam pemecahanmasalah sistem ekskresi, siswa diberi kesempatanuntuk bertanya.Kegiatan penutup dilaksanakan dengan guru menyimpulkan dan memberikan tugaskepada siswa secara individu untuk membuat laporanpemecahan masalah sistem ekskresi secara mandiri yangdikerjakan oleh setiap siswa, untuk dikerjakan diluar jam pembelajaran, dan memberikan tes diakhir pembelajaran. Hasil belajar siswadengan menggunakan metode ceramah dantanya jawab hasilnya lebih rendah dibandingkan dengan hasil belajar dengan menggunakan model pembelajaran problem based learning. Hal ini disebabkan oleh prosespembelajarannya kelas kontrol hanya monoton. Guruhanya menggunakan metode ceramah dantanya jawab. Konsep sistem ekskresi dibutuhkan suatuobservasi secara nyata sehingga siswadapat memahami apa yang sedangdipelajari jadi tidak hanya membayangkan. Jika siswa hanya diterangkan dan tidak ditunjukkan komponen-komponennya maka akan membuat siswa menjadi binggung serta menimbulkan miskonsepsi. Selain itu, yang menyebabkan hasil belajar kelas kontrol rendah yaitu proses pembelajarannya masih berpusat pada guru.

\section{Kesimpulan dan Saran}

\subsection{Kesimpulan}

Berdasarkan hasil penelitian dan pembahasan yang telah diuraikan di Bab IV diperoleh simpulan sebagai berikut: 
Jurnal Sosial Humaniora Sigli (JSH)

p ISSN : 2615-3688

$e$ ISSN : 2716-0270

http://journal.unigha.ac.id/index.php/JSH

1. Hasil analisis data N-gain menunjukan adanya peningkatan hasil belajar siswa yang signifikan di kelas eksperimen yaitu 0,60 dengan ratarata skor belajar pre-test dari 1,86 menjadi 3,16 di post-test. Sedangkan kelas kontrol menunjukan peningkatan hasil belajar siswa tidak ada signifikan dari pada hasil belajar siswa kelas eksperimen yaitu 0,30 dengan rata-rata skor pre-test 1,77 menjadi 2,45 di post-test.

2. Hasil analisis data dilakukan dengan menggunakan uji-t diperolah $t_{\text {hitung }}$ $(0,59)<t_{\text {tabel }}(1,68)$ dengan derajat kebebasan (dk) 46. Hal ini menunjukan bahwa hasil belajar siswa atau kemampuan awal siswa sebelum diberikan perlakuan di kedua kelas baik kelas eksperimen maupun kelas kontrol pada konsep sistem eksresi pada manusia di SMA Negeri 1 Jangka Buya dapat dikatakan sama. Hasil belajar post-test kelas eksperimen lebih tinggi dibandingkan dengan kelas kontrol yaitu $t_{\text {hitung }}$ $(5,91)>t_{\text {tabel }} \quad(1,68)$. Hal ini membuktikan bahwa penerapan model pembelajaran problem based learning dapat meningkatkan hasil belajar siswa pada konsel sistem eksresi pada manusia di SMA Negeri 1 Jangka Buya.

\subsection{Saran}

Berdarkan hasil penelitian yang telah dilakukan, peneliti menyarankan beberapa saran antara sebagai berikut:

1. Proses pembelajaran dengan menggunakan model problem based learning, peneliti harus bisa lebih memotivasi siswa untuk dituntut aktif agar terjalin komunikasi yang baik antara peneliti dengan siswa,

2. Penelitian ini hanya dilakukan dalam dua kali pertemuan, secara berkelanjutan hendaknya guru melakukan atau menggunakan strategi pembelajaran yang lain agar kemampuan siswa lebih meningkat,

3. Siswa perlu dibiasakan belajar kelompok untuk keberhasilan belajarnya, tentunya dengan bimbingan dan arahan dari guru.

4. Siswa perlu membiasakan diri ikut terlibat dalam proses pembelajaran di kelas. Mengemukakan pendapatnya dan menghargai pendapat siswa yang lain.

\section{Daftar Pustaka}

A'la M. 2010. Quantum Teaching. Yogyakarta: Diva Press

Anni Catharina dan Rifa'i Ahmad. 2009. Psikologi Pendidikan. Semarang: Universitas Negeri Semarang Press.

Campbell, dkk., 2003. Biologi. terj. Wasmen Menalu. Jakarta: Erlangga.

Depdikbud. 2005. Kamus Bahasa Indonesia. Jakarta: Balai pustaka.

Dimyati dan Mudjiono. 2009. Belajar dan Pembelajaran. Jakarta: Rineka Cipta.

Djamarah, Syaiful Bahri. 2002. Psikologi Belajar. Jakarta: Rineka Cipta.

Febriani, Selfy. 2017. Pengaruh Model Problem Based Learning (PBL) 
Jurnal Sosial Humaniora Sigli (JSH)

p ISSN : 2615-3688

$e$ ISSN : 2716-0270

http://journal.unigha.ac.id/index.php/JSH

terhadap Kemampuan Pemecahan Masalah Peserta Didik pada Mata Pelajaran Biologi Materi Pencemaran Lingkungan Kelas $\mathrm{X}$ MIA SMA N 6 Bandar Lampung. Jurnal Tadris Pendidikan Biologi, Vol. 8, No.1, Hal. 40-52.

Ferdinand P, Fictor dan Ariebowo, Moekti. 2009. Praktis Belajar Biologi 2 untuk SMA/MA Kelas $X I$. Jakarta: Pusat Perbukuan.

Hamalik, Oemar. 2005. Kurikulum dan Pembelajaran. Bandung: Bumi Aksara.

Harnitayasri. 2015. Efektivitas Model Pembelajaran Problem Based Learning (PBL) terhadap Hasil Belajar Biologi Siswa pada Materi Pencemaran Lingkungan di Kelas X SMA Negeri 2 Polewali. Jurnal Bionature. Vol. 16, No. 2, Hal. 103-109.

Irnaningtyas. 2013. Biologi Untuk

SMA/MA Kelas XI.Jakarta:

Erlangga.

Kamdi. 2007. Model-Model Pembelajaran. Jakarta: Grafindo.

Kimball, John W., 2006. Biologi. terj. Siti Soertami dan Nawangsari Sugir. Jakarta: Erlangga.

Kurniasih, I. dan Berlin, S. 2014. Implementasi Kurikulum 2013 Konsep dan Penerapan. Surabaya: Kata Pena.

Magdalena, Rita. 2016. Penerapan Model Pembelajaran Problem Based Learning (PBL) serta Pengaruhnya terhadap Hasil Belajar Biologi Siswa SMA
Negeri 5 Kelas XI Kota Samarinda Tahun Ajaran 2015. Jurnal. Vol. 13, No. 1, Hal. 299306.

Muhibbin Syah. 2007. Psikologi Belajar. Jakarata: Raja Grafindo.

Nadiya, Isti. Pengaruh Model Pembelajaran Problem Based Learning (PBL) Terhadap Penguasaan Konsep Siswa pada Materi Sistem Saraf. Jurnal Pendidikan Biologi.

Nasution, M. Yusuf. 2016. Perbedaan Hasil Belajar Siswa Menggunakan Model Project Based Learning dengan Problem Based Learning pada Materi Pencemaran dan Pelestarian Lingkungan Hidup. Jurnal Pelita Pendidikan.Vol. 4, No. 2. Hal. 122-127.

Noviar, Dian. 2015. Pengaruh Model Problem Based Learning (PBL) Berbasis Scientific Approach terhadap Hasil Belajar Biologi Siswa Kelas X Di SMA N 2 Banguntapan T.A. 2014 / 2015. Jurnal. Vol. 8, No. 2,Hal. 42-47.

Nurhidayat, A. 2011. Pengaruh Penerapan ModelPembelajaran Kooperatif Tipe Group InvestigationTerhadap Aktivitas dan Penguasaan Konsep Pada PokokBahasan Archaebacteria dan Eubancteria Siswa Kelas XSMAN 2 Bantul.Skripsi tidak diterbitkan UIN SUKA.

Omar Faiz dan David Moffat. 2003. Anatomy at a Glance. terj. Annisa Rahmalia. Jakarta: Erlangga. 
Jurnal Sosial Humaniora Sigli (JSH)

p ISSN : 2615-3688

$e$ ISSN : 2716-0270

http://journal.unigha.ac.id/index.php/JSH

Pratiwi, dkk., 2006. Biologi SMA. Jakarta: Erlangga.

Permendikbud. 2014. Penilaian Hasil Belajar Oleh Pendidik Pada Pendidikan Dasar Dan Pendidikan Menengah. Jakarta: Kementerian Pendidikan dan Kebudayaan.

Purnamaningrum, Arifah. 2012. Peningkatan Kemampuan Berpikir Kreatif Melalui Problem Based Learning (PBL) pada Pembelajaran Biologi Siswa Kelas X-10 SMA Negeri 3 Surakarta Tahun Pelajaran 2011/2012. Jurnal Pendidikan Biologi. Vol. 4, No. 3, Hal. 39-51.

Purnomo, dkk., 2009. Biologi: Kelas XI untuk SMA dan MA. Jakarta: Pusat Perbukuan

Rahayu. 2016. Pengaruh Model Problem Based Learning terhadap Berpikir Kritis dan Hasil Belajar Elastisitas Siswa Kelas XI SMA Negeri 7 Banda Aceh. Jurnal Pendidikan Sains Indonesia, Vol.04, No.02. Universitas Syiah Kuala.

Sajidan. 2016. Penerapan Model Pembelajaran Problem Based Learning (PBL) untuk Meningkatkan Kemampuan Proses Berpikir Kognitif Siswa Kelas XI MIPA-1 SMA Negeri 3 Surakarta Tahun Pelajaran 2015/2016. Jurnal Inkuiri. Vol 5, No. 2, Hal. 1-7.

Sanjaya, Wina. 2013. Strategi Pembelajaran Berorientasi Sandar Poses Pendidikan. Jakarta: Kencana.
Sardiman. 2011. Interaksi dan Motivasi Belajar Mengajar. Jakarta: Rajagrafindo Persada.

Saragih, Lusndico. 2017. Pengaruh Model Pembelajaran (Problem Based Learning dan Konvensional) Terhadap Keterampilan Proses Sains dan Hasil Belajar Siswa Sekolah Menengah Pertama. Jurnal Pendidikan Biologi, Vol. 6, No. 2. Universitas Negeri Medan.

Setiadi. 2007. Anatomi dan Fsiologi Manusia. Yogyakarta: Graha Ilmu.

Slameto. 2003. Belajar dan Faktor-Faktor Yang Mempengaruhinya. Jakarta: Rineka Cipta.

Sudjana. 2005. Metoda Statistika. Bandung: Tarsito.

Sudjana, Nana 2008. Dasar-Dasar Proses Belajar Mengajar. Bandung: Sinar Baru Aglesindo.

Sugiyono. 2009. Metode Penelitian Pendidikan (Pendekatan Kuantitatif, Kualitatif, dan $R \& D$ ). Bandung: Alfabeta.

Suprijono, A. 2010. Cooperative Learning. Yogyakarta: Pustaka Belajar.

Zuraida. 2019. Pengembangan Perangkat Pembelajaran IPA Model Learning Cycle 5E Untuk Melatihkan Kemampuan Berpikir Kreatif Siswa SMP Negeri 2 Kembang Tanjong. Jurnal Sains Riset. ISSN: 2088-0952 
Jurnal Sosial Humaniora Sigli (JSH)

p ISSN : 2615-3688

$e$ ISSN : 2716-0270

http://journal.unigha.ac.id/index.php/JSH 